\title{
The Influence of Law and the Coping Strategies of Contemporary Social Thought on the Ideology and Moral of College Students
}

\author{
Yu Hong \\ Teaching Department of Ideological and Political Theory, Xichang University, Xichang 615000, China
}

Keywords: social trend of thought; ideological and moral; influence law; coping strategy; Political Education

\begin{abstract}
With the globalization of economy, culture and information, the influence of contemporary social thoughts on Chinese college students is becoming more and more important. On the one hand, it brings positive effects to college students, such as self improvement and growth, and on the other hand, it also has a negative impact, especially in politics, ideology, morality, habits and habits. This study analyzes the characteristics of College Students' behavior habits under the current social ideological trend, and summarizes the influence rules of contemporary social trend of thought on College Students' ideology and morality. According to the analysis and summary, finally the strategy of strengthening the ideological and political education of College Students under the current social ideological trend has been put forward, which provides a valuable reference for the research of College Students' Ideological and political education.
\end{abstract}

\section{Introduction}

Social trend of thought is a theoretical form formed on the basis of social psychology under certain social and historical background. It has a certain trend of thinking that has considerable influence on the society within a certain range. Contemporary social thought is mainly refers to the members of society since the reform and opening up, the thought and behavior of some theory is larger, and has a certain philosophy, politics and economics, social thoughts cannot be separated from the relevant social background exists, its influence has important significance for social change and development. In the background of the current social trend of thought, only to strengthen the ideological and political education of college students can improve their ideological and moral character, and then lead the social trend of thought.

\section{Characteristics of Ideological and behavioral habits of College Students under the background of contemporary social trend of thought}

Under the background of contemporary social trend of thought, the characteristics of College Students' Ideological and behavioral habits are mainly reflected in four aspects, including independence consciousness, values, information reception and personality highlights.

(1) First of all, the independent concept of contemporary college students is strong, but the ability of self management is poor. In contemporary society, most college students have better birth conditions, their self-restraint ability is poorer, their status in family is relatively high, they are used to express their wishes, and their families are prepared for their own convenience and lack of self-care ability.

(2) Under the influence of contemporary social trend of thought, the values of college students are diversified. Their mainstream values are getting lower and lower in their minds than they have been blurred, such as collectivism and devotion.

(3) Under the background of information age, knowledge and information of college students accept is very large, but too much information will make them lose their direction and goal of their own, change some negative information and ideas will often cause their thoughts and behavior, to make a lot of college students is the ability to distinguish non drop from corrosion. Bad moral and behavioral habits, college students are difficult to form the habit of thinking and good moral 
behavior, make them easy to get lost.

(4) In the background of contemporary social thought, highlighting the personality of the students very much, everyone has a unique view for different things, because each person's character is not the same, it is difficult to form a good team spirit, so that they concern themselves only in social thought under the influence of no public moral consciousness.

\section{The influence of contemporary social thought on the ideological and moral of College Students}

The social trend of thought refers to the ideological trend which reflects the social and political situation in a certain period or stratum which has a great influence on the social and political situation at that time. Its influence on College Students' Ideological and moral is very complex, including in politics and economy, religion and literature etc., These thoughts will affect the choice of College Students' ideals and beliefs, thereby affecting the cultivation of College Students' Ideological and moral habits and behavior habits, which are embodied in the following aspects.

\subsection{The influence of Postmodernism Thought}

The trend of post modernism is mainly a cultural trend in western countries. It calls for freedom, value and dignity, and encourages multiple thinking styles, which is of positive significance for the cultivation of College Students' good moral character. But the postmodernism also preaches nihilism and pluralistic values, it is easy to make students willing to relax and enjoy the material, make students become no sense of responsibility, and even the loss of morality, extreme individualism and egoism, so that their ideals and beliefs become distorted.

\subsection{The influence of Consumerism Thought}

Consumerism is the social trend of thought that puts the self satisfaction and enjoyment of the first place in the society. This kind of ideological pursuit is too materialistic, and expands its demand desire by constantly pursuing new consumer goods, so that it is easy to form comparisons and consume for consumption. Influenced by this trend of thought, it is easy for college students to discard the virtues of traditional thrift and to pursue the lifestyle of high consumption and lose frugality, and pursue the way of enjoying life. Secondly, consumerism is easy for college students form the habit of thinking and behavior of mutual competition, and become hedonism and vanity, for the matter over valued, so that students get lost, the loss of the most basic moral principle, and even go on the road of crime.

\subsection{The influence of the ideological trend of Pragmatism}

Pragmatism is a struggle of action and pragmatic thought, this thought with China's current social change is consistent, in the social transformation period, college students to participate in social work will face great pressure, pragmatism and students thinking can resonate, so that the value orientation of college students with a strong pragmatism color. Pragmatism can promote college students to strive for students and establish sense of struggle, but it also makes their self consciousness too inflated, resulting in a weak sense of collective consciousness, neglecting social values, forming wrong values, and not conducive to good moral cultivation.

\section{Strengthening the ideological and political education of college students to lead the current social trend of thought}

Through the ideological and moral influence on Contemporary Social Thoughts on College Students' analysis, it has been found that the development of contemporary social thoughts on College Students' Ideological and moral good has positive effect already, also have the negative effect, as long as the strengthening of Ideological and political education, a reasonable guide effect to social thought, make reasonable countermeasures, in order to suppress the negative effects of social thought repeat, play a positive role. 


\subsection{Strengthening college students' ability to distinguish the current social trend of thought}

In the contemporary social thought can be divided into China, Marx thought and Marx thoughts, to identify students in social thought, certainly not simply completely or completely negative, we should grasp the overall identification using scientific methods, and then distinguish between.

\subsection{Optimizing the transmission way of contemporary trend of thought}

\subsubsection{Strengthening the supervision of mass media}

The mass media is one of the main carrier of students receiving information, for the dissemination of some bad information should be strictly limited the scope of its spread, or directly will be canceled, to strengthen the supervision of the news, to increase the social positive energy report, reduce the spread of negative news, especially overseas dissemination of harmful information need strict supervision.

\subsubsection{Standardize the way of classroom communication}

University classroom is the main stabilization for college students' Ideological and political education. Therefore, we should strengthen the effect of Ideological and political education in class, especially in Ideological and political theory class, we should increase the propaganda of socialist core values and refute the counter mainstream social trend of thought.

\subsubsection{Purify the social atmosphere}

The guiding role of thinking and behavior of college students in the social atmosphere is very strong, therefore, purify the social atmosphere will also actively promote the students good moral form, it is necessary to increase the social reward system, to establish a reasonable and advanced deeds of socialist moral model, strengthen the construction of a clean government, strengthening occupation moral construction, guide students to have the correct value orientation.

\subsection{Strengthening ideological and political education in Colleges and Universities}

\subsubsection{The methods of innovative work.}

In the information age, the ideological and moral education of college students need to actively explore innovative ways, through multimedia and digital information display technology, to eliminate the negative effects of Social Thought on college students to produce, spread positive energy, promote the students good moral cultivation.

\subsubsection{Combine the solution of the thought and the practical problems}

To explore the development of the college students thought of law, starting from the practical problems, such as learning problems, employment problems, relationship problems and relationship problems, take effective way of education, strengthen the education of patriotism and the ideals and beliefs of college students, and try to solve the specific problems encountered by students in learning and life.

\subsubsection{Developing and perfecting Marx doctrine}

To strengthen the Marx doctrine of faith, and will share the results of the Marx doctrine theory Chinese to students, let it become the sharp weapon of students to overcome various ideological problems, the Marx doctrine is more convincing, the only way to make social thought decadent ideas of self breaking, avoid social thought on the ideological and moral formation of negative effect the full use of its positive role, is college students can lead the social thoughts in the ideological and moral.

\section{Conclusion}

The influence of current social trend of thought on the ideological and moral of college students is diversified. This study summarizes the characteristics of College Students' behavior habits under 
the current social ideological trend, explores the influence rules of contemporary social trend of thought on College Students' ideology and morality, and finally puts forward strategies for college students' Ideological and political education. With the change of society, the new trend of social thought will not continue to appear. This requires us to correctly guide and educate college students through ideological and political education, so as to help college students establish the right ideals and lead the social trend of thought.

\section{References}

[1] Wang Jianguang. Contemporary social trend of thought and its challenge to China [J]. Exploration and Free Views, No.10, (2004). p.14-16

[2] Wang Yonggui. The western main ideology affecting the construction of the mainstream ideology in China: A Perspective of [J]. Social Science Research, No.1, (2007), p.60-64

[3] Li Bensong. The influence of Social Thought on the ideological and political education of college students [J]. Ideological and Political Education Research. Vol.26(04), (2010) , p.117-119

[4] Zhang Xiaohong. Strengthen the study of contemporary Chinese social trend of thought [J]. Hubei Social Science. No.12, (2005), p.5-8

[5] Wu Yize. The effective measure and cultivation path of College Students' values from the perspective of cultural identity [J]. Journal of Higher Education, No.22, (2017), p.1-3

[6] Liu Meng. Research on the value education of college students by microculture [J]. Journal of Yuncheng University. Vol.35(05), (2017), p.82-85

[7] Liu Chunfeng. The influence of weblive on the values of college students and the Countermeasures of [J]. Rural Economy and Science-Technology. Vol.28(13), (2017) , p.286-288

[8] Yu Xiao. The Development of College Students' Values in the Information Age [J]. The Guide of Science \& Education, No.07, (2017) , p.1-2

[9] Cao Jialiang. A cultural analysis on the College Students' socialism values [J]. Theoretic Observation, No.7, (2017), p.131-134

[10] Liu Tian. On the influence of network culture on the values of college students [J]. Development. No.03, (2017), p.72-73

[11] Wang Lihua. Thinking of strengthening the core value system education of College Students under the influence of contemporary social trend of thought [J]. The Party Building and Ideological Education in Schools. No.03 (2008), p.55-57

[12] Zhang Naigang, Lu Jinli. Analysis of the relationship between social thoughts and youth[J]. Journal of Changchun Institute of Technology(Social Sciences Edition). Vol.8(04), (2007) , p.23-26

[13] Yang Zengdong. On the importance of Ideological and Political Education Research on the law of social thought derivation and development [J]. The Party Building and Ideological Education in Schools. No.11, (2007), p.22-24

[14] Chen Lijuan. A Primary Exploration on the Education of College Students'Socialist Core Value Under the Multicultural Background [J]. Journal of Guangdong Communication Polytechnic. Vol.13(03), (2014), p.126-128

[15] Gao Zhongjian, Yan Lichao. The Negative Influence on Value Orientation of the Moral Education under Culture Conflicts and the Countermeasures[J]. Journal of Henan Normal University (Philosophy and Social Sciences Edition), Vol.36(01), (2009) , p.249-251

[16] He Xiaochun, Chen Xue. A review of the educational research on the socialist core values of College Students under the multicultural background [J]. Education Exploration. No.03, (2014), p.30-31 